\title{
RESPONSE OF MICROPROPAGATED SUGARCANE VARIETIES TO INOCULATION WITH ENDOPHYTIC DIAZOTROPHIC BACTERIA
}

\author{
André Luiz Martinez de Oliveira' ${ }^{1 *}$; Erineudo de Lima Canuto ${ }^{\text {; }}$ Verônica Massena Reis ${ }^{2}$; José Ivo Baldani ${ }^{2}$ \\ ${ }^{1}$ Ciência do Solo, Instituto de Agronomia, Universidade Federal do Rio de Janeiro, Rio de Janeiro, RJ, Brasil. \\ ${ }^{2}$ Embrapa/Agrobiologia, Seropédica, RJ, Brasil.
}

This paper corresponds to an "extended abstract" selected for oral presentation in the $22^{\text {nd }}$ Brazilian Congress of Microbiology, held in Florianópolis, SC, Brazil, in November 17-20, 2003

\begin{abstract}
Previous studies estimated that sugarcane could obtain up to $60 \%$ of total nitrogen accumulated from BNF. Here a mixture of five endophytic diazotrophic strains was tested in a field trial, inoculated in two micropropagated sugarcane varieties and three locals, to determine the effects on commercial crop conditions. The sugarcane plantlets were inoculated in vitro, and after 17 months of growing in the field, the productivity and BNF contribution showed to be influenced by the plant genotype and soil type. The highest BNF contributions was observed in the poorest soil for both varieties. Smaller increases in productivity were observed for SP 701143 variety grown in soil with low or medium fertility. In contrast, a decrease in the stem productivity was observed in the SP 813250 variety grown in the three localities.
\end{abstract}

Key words: endophytic bacteria inoculation, biological nitrogen fixation, plant growth promotion bacteria, sugarcane.

\section{INTRODUCTION}

Research studies using ${ }^{15} \mathrm{~N}$-isotopic dilution technique estimated than more than $60 \%$ of total nitrogen accumulated in some sugarcane varieties were derived from BNF (2). Recent inoculation studies using micropropagated sugarcane plants showed a maximum BNF contribution up to $30 \%$ of total Nitrogen, obtained with a mixture of five diazotrophic bacteria species (1). In this work, the BNF contribution and cane productivity of the inoculated micropropagated sugarcane plants with the same mixture of endophytic bacteria was evaluated in a field trial. The plants were grown in three different locations, comprising different soil fertility levels.

\section{MATERIALS AND METHODS}

Endophytic bacteria used in the mixture to inoculate the sugarcane plants are listed in Table 1.
Table 1. Mixture of inoculant used in this study, and isolation sources.*

\begin{tabular}{lcccc}
\hline \multicolumn{1}{c}{ Bacteria species } & Sign & Strain & $\begin{array}{c}\text { Plant } \\
\text { tissue }\end{array}$ & $\begin{array}{c}\text { Sugarcane } \\
\text { variety }\end{array}$ \\
\hline G. diazotrophicus & Gd & BR 11281 & Roots & Saccharum sp. \\
H. rubrisubalbicans & Hs & BR 11335 & Roots & SP 701143 \\
H. rubrisubalbicans & Hr & BR 11504 & Stems & SP 701284 \\
A. amazonense & Aa & BR 11115 & Roots & SP 775181 \\
Burkholderia sp. & Bk & BR 11366 & Buds & SP 711406 \\
\hline
\end{tabular}

*Culture collection, Embrapa/Agrobiologia

Plant inoculation was performed as described by Oliveira et al. (1). The strains were grown overnight in Dyg's liquid media, and an initial inoculum of $2.0 \times 10^{7} \mathrm{cells} / \mathrm{ml}$ of each species was inoculated in the MS medium. The plants were incubated for 120 hours at 12 -hour fotoperiod at $30^{\circ} \mathrm{C}$. The micropropagated

*Corresponding author. Mailing address: Curso de Pós-Graduação em Agronomia, Ciência do Solo, Instituto de Agronomia, Universidade Federal do Rio de Janeiro. Km 47 da antiga rodovia Rio-São Paulo. 23890-000, Seropédica, RJ, Brasil. Tel: (+5521) 2682-1308. Fax: (+5521) 2682-1210. E-mail: almoliva@yahoo.com.br 
sugarcane varieties SP 701143 and SP 813250 were provided by Copersucar (SP), and grown in three different locations in soil with different fertility level. The stem productivity was evaluated in 16 months old plants grown in the field. The BNF contribution was measured 9 months after field growth, using a mass spectrometer Delta Plus (Finnigam, UK). The following formula was applied to estimate the BNF:

$$
\% \mathrm{BNF}=100 \mathrm{x} \frac{\left(\delta^{15} \mathrm{~N} \text { control plant }-\delta^{15} \mathrm{~N} \text { test plant }\right)}{\left(\delta^{15} \mathrm{~N} \text { control plant }\right)}
$$

\section{RESULTS}

The cane yield obtained in Ultisol (low fertility soil) was significantly lower than the cane productivity of the Oxisol or the Alfisol (medium and high fertility soil, respectively) for both varieties (Fig. 1).

A significant BNF contribution for the nitrogen nutrition of sugarcane plants for both varieties was detected by the isotopic analysis. However, the positive income was observed only for the experiments performed at the Ultisol and Alfisol soils. It was impossible to run the isotopic analysis of the plants grown in the Oxisol soil probably because the massive use of nitrogen fertilisation in previous experiments (Table 2).

\section{DISCUSSION}

A different response to inoculation was observed for each tested sugarcane variety. The inoculation showed a small

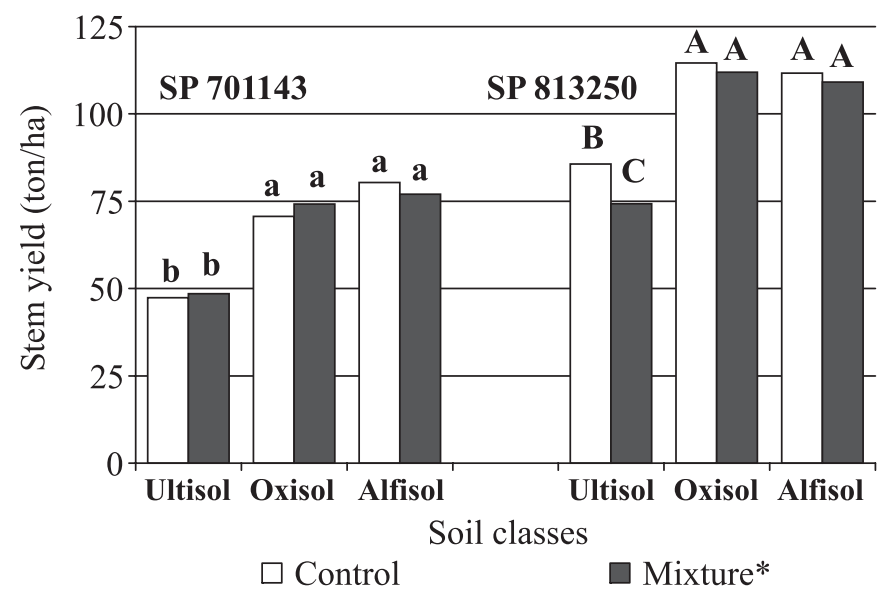

Figure 1. Stem productivity of two sugarcane varieties (16 months old plants) grown in three soil classes. Same letters do not differ statistically by LSD test at $5 \%$ of confidence. Means of 12 plots.
Table 2. Biological nitrogen fixation contributions to nitrogen nutrition of two endophytic diazotrophic bacteria inoculated sugarcane varieties grown in three soil classes.

\begin{tabular}{llcc}
\hline \multirow{2}{*}{ Soil Class } & \multicolumn{2}{c}{$\%$ of total N derived from } \\
& \multicolumn{2}{c}{ BNF } \\
\hline \multirow{2}{*}{ Locality } & Var SP & Var SP \\
\cline { 2 - 4 } Ultisol & Seropédica - RJ & $18.2 \%^{*}$ & 813250 \\
Oxisol & Piracicaba - SP & $-4.5 \%$ & $31.4 \% *$ \\
Alfisol & Jaú - SP & $13.4 \% *$ & $-1.1 \%$ \\
\hline
\end{tabular}

* Significant at LSD test with $95 \%$ of confidence, obtained by comparison of $\mathrm{d}^{15} \mathrm{~N}$ values of inoculated plants with $\mathrm{d}^{15} \mathrm{~N}$ values of control plants. * See in Table 1.

increase (not significant) on the productivity of the SP 701143 variety when cultivated on Oxisol and Ultisol soil types, and decreased the stem yield when grown in the Alfisol. The SP 813250 variety showed a decrease of the stem yield with the inoculation, mainly for the plants grown in the Ultisol. This could be due to the breeding characteristics of the cane varieties used, where the SP 701143 was breeded to grow in low fertility soil classes, while the SP 813250 was much adapted to medium to high fertility soil classes. Those characteristics could influence the capacity of association with the inoculated bacteria.

In Alfisol, the BNF contribution as evaluated for the SP 701143 variety was up to $13.4 \%$ of total nitrogen accumulated in the plant, while in the SP 813250 variety it corresponded only to $5.9 \%$ of total N. Evaluations of plants grown in the Ultisol showed that the inoculation contributed with up to $18.2 \%$ of total nitrogen in the SP 701143 variety, while $31.4 \%$ of total N was derived from BNF in the SP 813250 variety (Table 2). Although, it was shown that substantial part of nitrogen was derived from the BNF, these results did not reflect in the stem productivity.

The results suggest that inoculation of the sugarcane crop seems to be more successful mainly in crops cultivated in soil classes with low fertility. In addition, the commercial variety used also influenced the interaction with the inoculated bacteria. The better understanding of the plant-bacteria interaction, the selection of endophytic diazotroph strains as well as sugarcane varieties, need to be exploited to obtain the maximum benefit from BNF.

\section{ACKNOWLEDGEMENTS}

The authors thank to CAPES, PRONEX II and PADCT III for financial support, and Copersucar (Piracicaba-SP), UFRRJ and Embrapa-Agrobiologia for logistical supports. 


\section{RESUMO}

\section{Resposta da inoculação com bactérias diazotróficas endofíticas em duas variedades micropropagadas de cana-de-açúcar}

Experimentos anteriores estimaram que a cana-de-açúcar pode obter até $60 \%$ do $\mathrm{N}$ acumulado via fixação biológica de nitrogênio (FBN). Neste trabalho, os efeitos da inoculação da mistura de cinco espécies de bactérias diazotróficas endofíticas foram testados em duas variedades de cana-de-açúcar micropropagadas, sob condições de campo. Após 17 meses de crescimento, a produtividade e a FBN apresentaram influência do genótipo vegetal e da localidade de cultivo. As maiores contribuições via FBN foram observadas no solo de menor fertilidade, para ambas variedades de cana-de-açúcar. Pequenos aumentos de produtividade foram observados para a variedade SP 701143 nos solos de baixa e média fertilidade. Por outro lado, a inoculação na variedade SP 813250 apresentou decréscimo de produtividade nos três tipos de solo testados.

Palavras-chave: inoculação com bactérias endofíticas, fixação biológica de nitrogênio, bactérias promotoras do crescimento vegetal, cana-de-açúcar.

\section{REFERENCES}

1. Oliveira, A.L.M.; Urquiaga, S.; Döbereiner, J.; Baldani, J.I. The effect of inoculating endophytic N2-fixing bacteria on micropropagated sugarcane plants. Plant Soil, 242(02):205-215, 2002.

2. Urquiaga, S.; Cruz, K.H.S.; Boddey, R.M. Contribution of nitrogen fixation to sugarcane: nitrogen-15 and nitrogen balance estimates. Soil Sci. Soc. Am. Proc., 56:05-114, 1992. 